УДК 005.963.1:005.591.6.

DOI: $10.15673 /$ fie.v11i1.1296

\author{
Козак К.Б. \\ кандидат економічних наук, доцент \\ кафедра менеджменту та логістики \\ E-mail: kozakkate.coach@gmail.com \\ ORCID ID: 0000-0002-8099-6607 \\ Бойчук К.Г. \\ студентка 4 курсу факультету менеджменту, маркетингу та логістики \\ Одеська національна академія харчових технологій \\ вул. Канатна 112, м. Одеса, Україна, 65039 \\ E-mail: likina.ua@gmail.com
}

\title{
ІННОВАЦІЙНІ ТЕХНОЛОГІЇ НАВЧАНЯ ПЕРСОНАЛУ
}

Більшість підприємств використовують звичайні технології управління та навчання персоналу, при цьому підприємства прагнуть швидкого розвитку та виходу на нові світові ринки. Це неможливо, якщо використовувати застарілі технології щодо управління в цілому підприємствами та зокрема персоналом. Відомо, що більшість закордонних підприємств намагаються слідкувати за змінами у багатьох галузях та впроваджують нові інноваційні технології, що надають їм перевагу та підвищують рівень конкурентоспроможності.

В статті розглянуто сучасні технології навчання персоналу: сторітеллінг, shadowing, secondment, buddying, що наддадуть змогу вітчизняним підприємствам по-новому поглянути на організацію праці та ефективно управляти своїм персоналом, а також деякі методи, що набули популярності застосування на європейських підприємствах і вже довгий час практикуються та не мають поки що такого визнання на Україні. Проаналізовано та описано застосування сучасних методів навчання персоналу та переваги, що отримують співробітники після проходження навчання за новими технологіями. Наведені приклади застосування інноваційних технологій на підприємствах України та побічні ефекти, з якими може зіткнутись підприємство, керівник і працівник.

Ключові слова: управління персоналом, навчання персоналу, працівники, сторітеллінг, shadowing, secondment, buddying.

This work is licensed under a Creative Commons Attribution 4.0 International License http://creativecommons.org/licenses/by/4.0/

Постановка проблеми та її зв'язок з важливими науковими та практичними завданнями. Світ не стоїть на місці - на заміну старим технологіям, щодо управління будь-якими ресурсами підприємств, приходять удосконалені нові. Сьогодні Україна живе в час, коли технології управління, якими раніше користувались підприємства та їх керівники, на даний момент $є$ дещо застарілими, іноді неактуальними, іноді неефективними. Відомо, що кожна людина має свої особливості, а старі технології щодо управління персоналом не враховують детального (індивідуального) підходу, як до особистості. Так, деякі з працівників відразу розуміють своє призначення в житті підприємства та спрямовують свою діяльність на досягнення його стратегічних цілей, а декому потрібно час, потрібна допомога з боку керівництва, щоб ефективно виконувати свою роботу. Наприклад, в країнах Європи вже довгий час використовують новітні технології управління персоналом, а саме, навчання, що дає змогу підприємствам підвищувати продуктивність персоналу та сприяти зростанню фінансово-економічних показників діяльності підприємства. Українським підприємствам слід звернути увагу на досвід світових підприємств, щодо на- вчання персоналу та запровадити нові інноваційні технології, що стане запорукою на шляху до економічної стабільності та розвитку підприємства.

Аналіз останніх публікацій по проблемі. Вивчення нових технологій управління персоналом та його навчання пов'язане 3 тим, що звичайні технології недостатньо ефективні у нових соціальних та економічних умовах господарювання підприємства, а використовуючи застарілі технології навчання, суб'єкти управління іноді не справляються 3 покладеними на них обов'язками щодо розвитку, мотивації та спонукання персоналу до результативної праці. Такі вітчизняні і закордонні вчені: Гавриш О.А., Довгань Л.С., Крейдич I.М., Семенченко Н.В., П. Друкеpa, М. Малреннан вивчають проблематику та задачі інноваційних технологій управління персоналом та його навчання. Д. Кенвелл, Д. Сазерленд описують застосування економічно ефективних технологій управління персоналом та систему поглибленого навчання персоналу. В. А. Вергун, О. І. Ступницький досліджують інноваційні зміни, що відбуваються в системі управління персоналом та розглядають тенденції розвитку ринку управлінських послуг. Але, деякі питання, впровадження та адаптації інновацій- 
них методів навчання на підприємстві, не розкриті у повній мірі, а технології що вже застосовуються в Європі, досі недосконало описані, що запобігає їх використанню на українських підприємствах. Інноваційні технології навчання персоналу та його управління в сучасних економічних умовах все дедалі більше привертають до себе увагу.

Формулювання цілей дослідження. Проаналізувати, освітити та визначити ефективність інноваційних технологій щодо навчання персоналу, як елементу механізму управління персоналом, які застосовуються за кордоном та ще не набули достатнього розповсюдження та застосування на підприємствах України.

Виклад основних результатів та їх обгрунтування. Деякі українські підприємства вже впрова- дили, або намагаються впровадити новітні технології управління, які пов'язані з навчанням персоналу, що підвищує вмотивованість та сприяє зростанню продуктивності праці. Більшість керівників вже використовують у практиці управління такі технології навчання персоналу як: робочі групи, коучинг, тренінги, дистанційне навчання тощо. Але багато технологій щодо навчання, які застосовують провідні компанії в Європі, ще не набули активного розповсюдження на вітчизняних підприємствах.

Так, на сьогодні активно застосовуються сучасні методи навчання персоналу, що прийшли з Заходу, наприклад такі, як: сторітеллінг, shadowing, secondment, buddying. Про поширеність тих чи інших технологій навчання в країнах СНД і на Заході свідчать статистичні дані (табл.1) [7].

Таблиця 1

Поширеність технологій навчання персоналу"

\begin{tabular}{|c|c|c|}
\hline Метод навчання & Країни СНД, \% & Західні компанії, \% \\
\hline 1. Модульне навчання & 83 & 81 \\
\hline 2. Дистанційне навчання & 37 & 54 \\
\hline 3. Наставництво & 78 & 72 \\
\hline 4. Робочі групи & 60 & 65 \\
\hline 5. Сторітеллінг & 58 & 80 \\
\hline 6. Навчання методом «shadowing» & 1 & 71 \\
\hline 7. Навчання методом «secondment» & 1 & 65 \\
\hline 8. Навчання методом «buddying» & 5 & 85 \\
\hline
\end{tabular}

*складено авторами на основі джерел [7]

Отже, статистичні дані свідчать про те, що не значного розповсюдження та застосування в країнах СНД, набули технології навчання персоналу, такі як модульне навчання, дистанційне навчання, наставництво та інші. Також, 3 табл. 1 видно, що в країнах Свропи всі наведені у таблиці технології застосовуються в рази частіше, саме тому їм вдається на кращому рівні приділяти увагу навчанню та розвитку персоналу. Враховуючи досвід підприємств Європи та СНД, щодо навчання персоналу та ефективності технологій, що використовуються, слід більш детально проаналізувати описані методи навчання, які ще не набули широкого розповсюдження в Україні та визначити їх ефективність.

Так, однією з інноваційних технологій навчання персоналу є метод shadowing. Метод застосовується для наявного персоналу та знаходження потенційного робітника. Завдяки shadowing нові співробітники проводять перші кілька днів або тижнів 3 більш досвідченим співробітником, для того щоб освоїти його роботу. [10] Метод полягає у тому, що за недосвідченим, новим робітником закріплюють наставника-професіонала, який працює на підприємстві деякий час. Новий робітник стає «тінню» професіонала та слідкує за його роботою, супроводжує професіонала на ділові зустрічі, наради (якщо це допускається політикою компанії). «Тінь» може наочно спостерігати за всією виконуваною роботою, отримати нові уміння та зрозуміти для себе чи впорається він 3 цією роботою.

Як показують дослідження [8], проведені в США, компанії широко використовують цей метод, щоб скоротити витрати на підбір персоналу, тобто на постійну заміну людей, які йдуть через те, що їх очікування не виправдалися. [8] На рис. 1 наведені переваги застосування методу Shadowing.

Метод схожий на вже відомий і розповсюджений метод навчання - наставництво. Але метод shadowing більш осучаснений і вдосконалений, він дозволяє охопити більшу низку аспектів навчання персоналу, пов'язану з полегшенням адаптації персоналу до нового місця роботи або донесення до персоналу чіткого розуміння виконуваних обов'язків.

Наступна інноваційна технологія - це метод навчання персоналу buddying. Buddying - це метод адаптації та обміну знаннями, який використовується для орієнтації нових співробітників. За новим співробітником закріплюється «друг». «Друг»- це наявний співробітник, який керує новим співробітником протягом перших кількох тижнів або місяців роботи. Мета обміну знаннями полягає в тому, щоб включити нові ідеї та технології, які покращують організацію праці. [13] Метод buddying полягає у тому, що новий співробітник завжди може звернутися за порадою до досвідченого співробітника («друга»). 


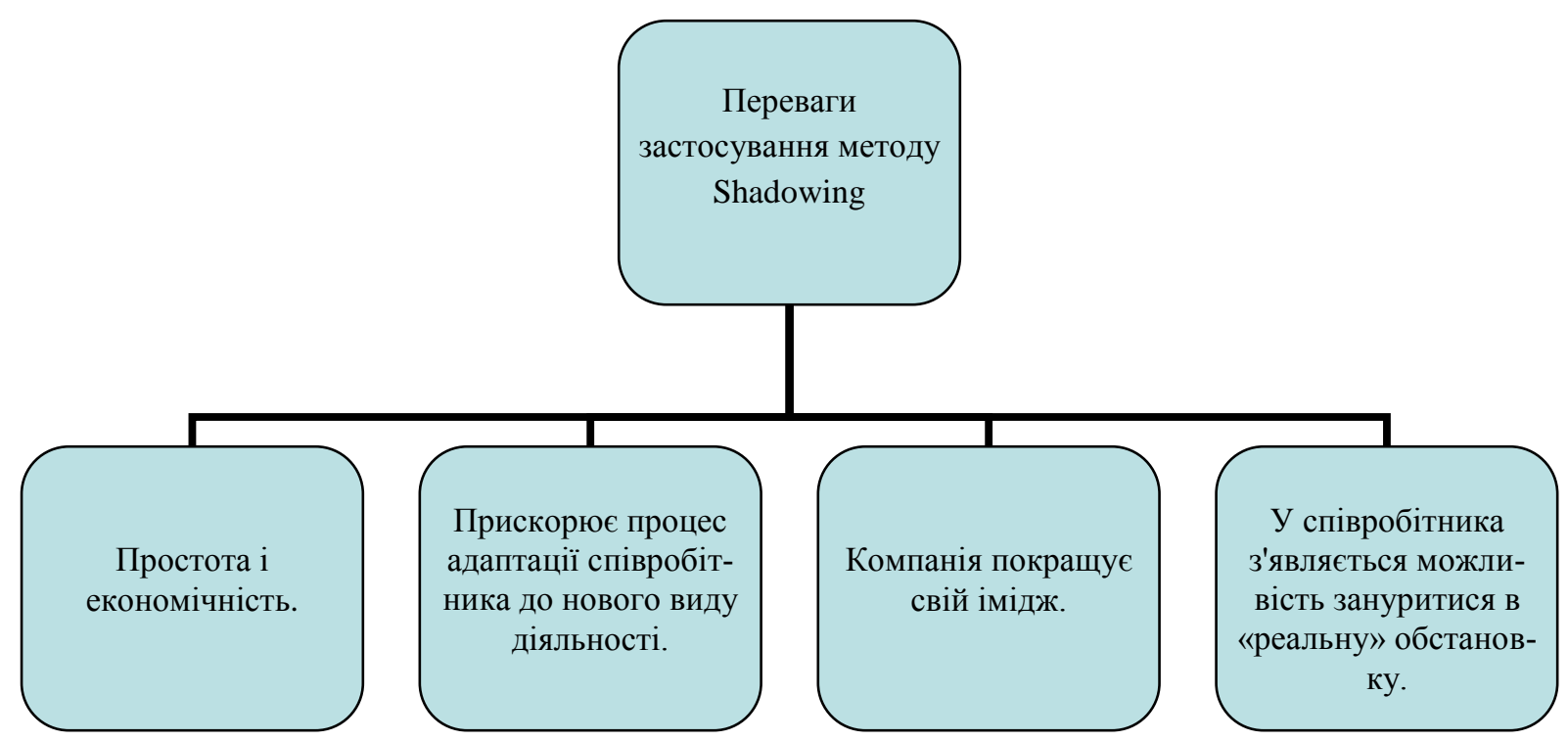

Рис. 1. Переваги застосування методу Shadowing [7]

«Друг» не керує, а лише допомагає, направляє та обидва співробітники знаходяться в рівних умовах. «Друг» $є$ помічником, який дозволить полегшити період адаптації та ознайомить нового робітника з політикою, культурою компанії, спрямує на досягнення поставлених цілей компанії. Це знижує напругу та призведе до плідного спілкування, отже, сприяє підвищенню продуктивності праці. На рис.2 наведено переваги методу Buddying [7] .

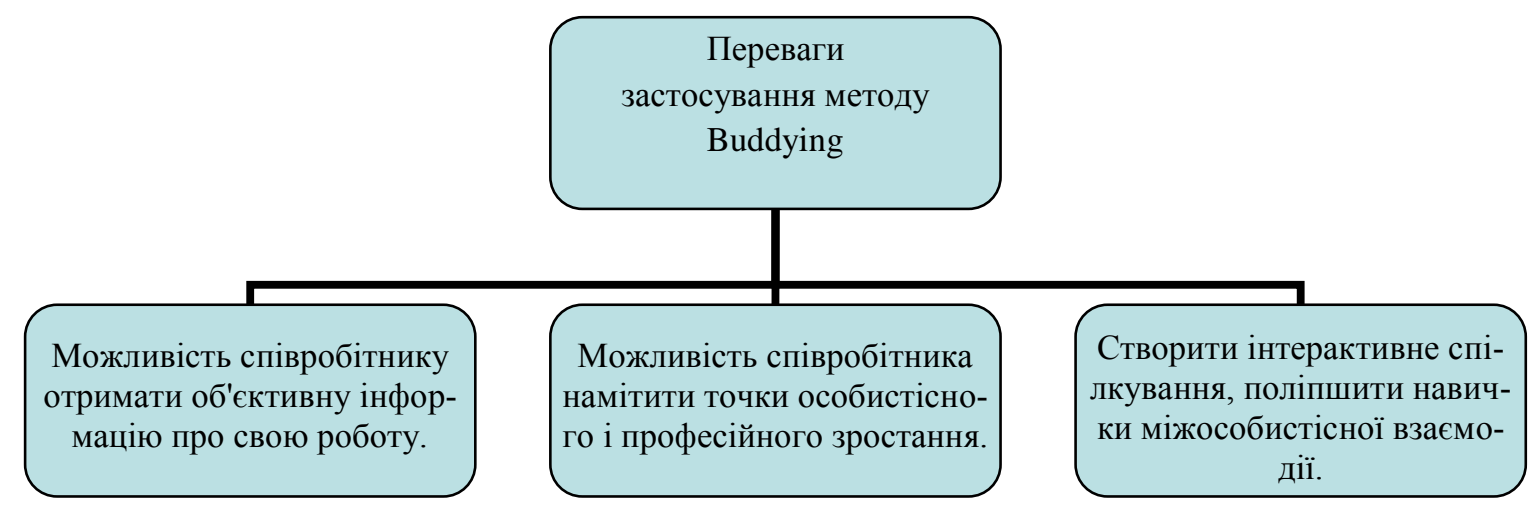

Рис. 2. Переваги застосування методу Buddying [7]

Але, на нашу думку, під час застосування даного методу підприємство може зіткнутися із таки- ми імовірними проблеми та наслідками (табл. 2).

Таблиця 2

\section{Негативні наслідки використання методу Buddying*}

\begin{tabular}{|l|l|}
\hline $\begin{array}{c}\text { № } \\
\text { п/п }\end{array}$ & \multicolumn{1}{c|}{ Характеристика проблеми } \\
\hline 1. & $\begin{array}{l}\text { Призначений друг не хоче бути другом. Якщо ваш співробітник не хоче бути другом, не вимагайте. } \\
\text { Замість цього, зрозумійте, чому ваш співробітник відмовляється і працюйте над цією проблемою. }\end{array}$ \\
\hline 2. & $\begin{array}{l}\text { Друг виконує роботу новачка. Одна з поширених причин: «Мені треба було б менше часу, щоб зро- } \\
\text { бити це самому». Ну, звичайно, так і буде. Це не означає, що один співробітник може або повинен } \\
\text { взяти на себе роботу іншого співробітника. }\end{array}$ \\
\hline 3. & $\begin{array}{l}\text { Друг перестає бути другом до того, як новачок буде готовий. Новачок і друг вже створили відноси- } \\
\text { ни. Якщо новий співробітник повинен створити нові відносини з другом-замінником, новий співро- } \\
\text { бітник з меншою ймовірністю поставте необхідні питання. }\end{array}$ \\
\hline
\end{tabular}


Отже, саме задля того щоб уникнути виникнення імовірних проблем та негативних наслідків, розглянемо принципи buddying. Так слід зробити наступне: обов'язково створити контекст довіри та конфіденційності; визначити потреби та очікування учасників методу, поставити цілі, яких слід досягти до закінчення терміну дії методу; узгодити, як часто будете взаємодія та протягом якого часу буде підтримуватися цей процес [6].

Ще одна технологія, що набула широкого розповсюдження за кордоном - це secondment. Secondment - тип відрядження відбувається, коли працівник (або група співробітників) тимчасово призначаються для роботи в іншій компанії або іншій ії відділах. Secondment буває внутрішнім (відрядження між відділами однієї компаніі) та зовнішній (відрядження в сторонню компанію).

Можливі причини для застосування Secondment:

- Створення сприятливих умов для розвитку кар'єри.

- Отримання нових навичок або досвіду.

- Надання персоналу для спільних короткострокових проектів.

- Створення сприятливих умов для уникнення звільнень [9].

Отже, як бачимо, secondment допомагає працівнику освоїти нові навички, новий досвід, який він отримує пропрацювавши деякий час на сторонню компанію. Робітнику надається можливість наочно споглядати процес організації праці на підприємстві. Працівник виконує коло своїх постійних обов'язків тільки в нових обставинах, що дає йому змогу поновому поглянути на виконувану ним роботу. Також ця технологія запобігає емоційному вигорянню пер- соналу, що дуже часто зустрічається у робітників, які віддано працюють вже довгий час на підприємстві. Користь для підприємства, що застосовує такий тип відрядження полягає у тому що, воно навчає свого працівника новим навичкам, сприяє підвищенню мотивації персоналу, розширює коло партнерських відносин з іншими підприємствами, здобуває репутацію хорошого роботодавця. Стороння компанія, що приймає працівника отримує свіжий, компетентний погляд та робітника, який буде виконувати будь-яку доручену йому роботу.

Нами було проаналізовано та визначено головні рекомендації щодо застосування методу Secondment. Так слід зробити наступне: створити письмову угоду про прикомандирування та як воно закінчиться; встановити, яка сторона зберігає контроль над трудовими відносинами; визначити кому повинен доповідати робітник в разі своєї відсутності, хвороби, відпустки; встановити процедури для оцінки, дисципліни та скарг; скласти угоду, що передбачає дотримання інструкцій і політики компанії.[11]

Наступна технологія - сторітеллінг. Сторітеллінг - це спосіб передачі інформації і знань, а також спонукання до бажаних дій за допомогою повчальних історій. Організаційний сторітеллінг - це інструмент менеджменту, який використовується для розуміння, інтерпретації та розповсюдження цінностей, норм, правил і принципів організаційної культури через використання корпоративних історій, міфів, легенд [2]. Організаційний сторітеллінг визначається, як опис минулих дій керівництва, взаємодій співробітників або інших внутрішньоорганізаційних, або позаорганізаційних подій. Ці історії зазвичай повідомляються неформально в межах компанії [14].

Таблиця 3

Типи історій для застосування сторітеллінгу*

\begin{tabular}{|l|l|}
\hline $\begin{array}{c}\text { № } \\
\text { п/п }\end{array}$ & \multicolumn{1}{c|}{ Тип історії } \\
\hline 1. & Історія про недотримання правил. \\
\hline 2. & Наскільки людяний начальник? \\
\hline 3. & Чи може людина піднятися знизу до самого верху? \\
\hline 4. & Чи не звільнять мене? \\
\hline 5. & Чи підтримає мене організація, якщо доведеться переїжджати? \\
\hline 6. & Як бос реагує на помилки? \\
\hline 7. & Як організація долає перешкоди? \\
\hline & *складено авторами на основі джерел [4] \\
\hline
\end{tabular}

Як видно з табл.3, сторітеллінг включає такі види історій: опис, як кращих, так і не вдалих прикладів роботи; історії, які просувають корпоративні цінності і принципи всередині компанії; історіїперсоналії - розповіді про побудову кар'єри будьяким співробітником, міфи про батьків-засновників компанії та ін.; антиісторії та історії-антивіруси. [4]

Отже, для ефективного використання технології сторітеллінгу пропонується наступне:

1. Розробити анкету та зібрати дані про персонал. Встановити поточні успіхи та невдачі в роботі кожного для можливого виявлення проблем.
2. Провести індивідуальні та спільні бесіди. Спільні бесіди покажуть, як спілкується кожен член колективу зі своїми колегами, як до нього ставляться. Індивідуальні бесіди з кожним окремо наддадуть зрозуміти кожного члена колективу, як особистість (вияснити мотивацію).

3. Проаналізувати отриману інформацію.

4. Узагальнити зібрану інформацію. Встановити, чи потребує кожен з працівників навчання і яку техніку навчання слід застосувати для кожного.

5. Розробити план навчання персоналу. Обговорити навчання 3 кожним працівником 
6. Слідкувати за навчанням, контролюючі та корегуючи похибки.

7. Після закінчення навчання провести бесіду 3 працівником. Визначити його мотивацію, як він вважає чи допомогло навчання.

8. Зробити висновки. Чи допомогло навчання (в цьому може допомогти п. 2). Продовжувати слідкувати за роботою персоналу для подальшої потреби в навчанні.

Деякі вітчизняні підприємства вже слідують тенденціям розвитку персоналу та впроваджують інноваційні технології управління та навчання персоналу. Так, наприклад, ТОВ «АГРОТЕХНІКА» співпрацює $з$ Луцьким національним технічним університетом. В рамках програми «JOB SHADOW DAYS» студенти проводять один день в різних відділах фірми та слідкують за роботою професіоналів. [1] ПП «Автомобільна школа «АС» - $€$ прибічником нововведень та використовує метод shadowing, адже метод shadowing не несе за собою великих витрат. Національний банк України у рамках програми secondment у 2017 році запросив до дослідницької команди Національного банку Магнуса Йонсона, економіста центрального банку Швеції. Запрошений економіст ініціював та долучився до низки дослідницьких проектів разом 3 працівниками банку [5].

Висновки та перспективи подальших досліджень. Під час розвитку економіки та держави розвивається й організація праці та підходи щодо управління підприємствами. Виникають нові методи управління персоналом, що призводить до виникнення інноваційних технологій навчання. На основі проведеного дослідження було встановлено, що світ вже використовує інноваційні технології навчання персоналу такі як сторітеллінг, shadowing, secondment, buddying тощо. Ці технології враховують економічний стан підприємства, специфіку його діяльності, індивідуальний підхід до працівників. В свою чергу отримання нових знань та навичок дає змогу підвищувати ефективність роботи працівників. Зазначимо, що враховуючи ймовірність виникнення певних негативних наслідків після використання інноваційних технологій навчання персоналу та враховуючи перехід до інноваційної моделі розвитку України, слід провести подальші дослідження в обраній області, щодо узагальнення понять, визначення показників оцінки щодо ефективності описаних технологій та результатів апробації нових технологій навчання персоналу на вітчизняних підприємствах.

\section{Література} 01.02.2019)

1. АГРОПРОМГРУПА «ПАН КУРЧАК»: [Веб-сайт]. URL: http://pankurchak.ua/ (дата звернення:

2. Новичкова А.В., Вокресенская Ю.В. Сторителлинг как современный инструмент управления персоналом // Интернет-журнал «Науковедение»: электрон. версия жур. 6 (25) 2014 ноябрь - декабрь. Нижний Новгород, 2014. URL: https://naukovedenie.ru/PDF/39EVN614.pdf (дата обращения: 01.02.2019).

3. Козак К.Б. Інновації в сфері управління персоналом на підприємстві // Зернові продукти i комбікорми. 2012. Т. 1, вип. 4. С. 8-13

4. Наставничество и сторителлинг как способы передачи знаний в рабочей среде // Executive.ru: [Beбсайт]. 2006. URL: https://www.e-xecutive.ru/education/glavy-iz-knig/349726-nastavnichestvo-i-storitelling-kaksposoby-peredachi-znanii-v-rabochei-srede (дата обращения: 01.02.2019).

5. Національний банк України: [Веб-сайт]. URL: https://bank.gov.ua/control/uk/index (дата звернення: 01.02.2019)

6. О методах обучения и развития персонала // HR-Portal: [Веб-сайт]. 2019. URL: http://hrportal.ru/article/o-metodah-obucheniya-i-razvitiya-personala (дата обращения: 01.02.2019).

7. Современные методы обучения персонала // Национальная Гильдия Профессиональных Консультантов: [Веб-сайт]. URL: http://www.ngpc.ru/forum2010/Articles/Learnining\%20methods.pdf (дата обращения: 01.02.2019).

8. «Тени» и «друзья» - методы обучения персонала, которых у нас пока нет // Executive.ru: [Веб-сайт]. URL: https://www.e-xecutive.ru/career/hr-management/344785-teni-i-druzya-metody-obucheniya-personala-kotoryh-unas-poka-net?scrolltop=SCROLLTOP (дата обращения: 01.02.2019).

9. Arranging a secondment: practical and legal considerations // Net Lawman: [Website]. URL: https://www.netlawman.co.uk/ia/secondment-agreements (viewed on: 01.02.2019).

10. Canwell D. Sutherland J. Student Resource Book for Edexcel. Cheltenham: Nelson Thornes. 2003. 276 p.

11. Eight steps to a successful secondment // Personnel Today: [Website]. URL: https://www.personneltoday.com/hr/eight-steps-to-a-successful-secondment/ (viewed on: 01.02.2019).

12. How 2 Buddy // AYE Conference: [Website]. URL: http://www.ayeconference.com/how-2-buddy/ (viewed on: 01.02.2019).

13. Implementing a buddy system in the workplace // Project Management Institute: [Website]. URL: https://www.pmi.org/learning/library/implementing-buddy-system-workplace-9376 (viewed on: 01.02.2019).

14. STORYTELLING: TRANSFERRING TACIT CORPORATE KNOWLEDGE IN DIFFERENT CULTURES A RESEARCH-IN-PROGRESS PAPER // Ecsocman: [Website]. URL: http://ecsocman.hse.ru/data/918/655/1219/storytelling.pdf (viewed on: 01.02.2019). 


\author{
Козак Е.Б. \\ кандидат экономических наук, доцент \\ кафедра менеджмента и логистики \\ E-mail: kozakkate.coach@gmail.com \\ ORCID ID: 0000-0002-8099-6607 \\ Бойчук Е.Г. \\ студентка 4 курса фракультета менеджмента, маркетинга и логистики \\ Одесская национальная академия пищевых технологий \\ ул. Канатная, 112, г. Одесса, Украина, 65039 \\ E-mail: likina.ua@gmail.com
}

\title{
ИННОВАЦИОННЫЕ ТЕХНОЛОГИИ ОБУЧЕНИЯ ПЕРСОНАЛА
}

В статье рассмотрено инновационные технологии обучения персонала. Данные технологии широко применяются в странах Европы, что способствует эффективному экономическому росту как предприятия, так и страны в целом. В странах СНГ и в Украине, в том числе, эти технологии не имеют большого количества приверженцев. Отечественные предприятия предпочитают старые проверенные годами технологии. Предприятия, в лице руководителей не всегда стремятся к новшествам. Для этого есть ряд факторов, которые сдерживают предприятие на пути к внедрению новшеств. Главными фракторами являются: невозможность введения новшеств из-за недостаточного количества финансовых средств или предприятие приверженец старых технологий и не стремится к усовершенствованию.

Внедрение новых технологий обучения персонала сторителлинг, shadowing, secondment, buddying не повлекут за собой больших затрат, откроют новые возможности организации труда на предприятии, что повлечет за собой большой потенциал для развития персонала. Инновационные технологии рассматривают работника как личность, учитывают индивидуальные потребности в обучении и получении новых знаний каждого работника отдельно.

В статье проанализированы инновационные методы обучения персонала. Приведены рекомендации для применения технологий управления и обучения персонала на предприятии. В статье описаны преимущества, которые приобретает предприятие, руководитель и работник, применяя инновационные технологии управления персоналом. Приведены примеры последствий, которых стоит опасаться предприятию.

Рассмотрены примеры возможных ситуаций, в которых стоит применять ту или иную технологию обучения, для эфффективного развития персонала. Описаны способы применения технологий, что влекут за собой стабильный рост, как личностного потенциала каждого работника, так и предприятия в целом. Охарактеризованы принципы на которых базируются инновационные технологии. Предложены рекомендации для эффрективного управления и обучения персонала, что дают возможность предприятию получить образованный персонал. Используя данные технологии, предприятие воспитывает того профессионала, который выведет предприятие на новый экономический уровень развития.

Ключевые слова: управление персоналом, обучение персонала, работники, сторителлинг, shadowing, secondment, buddying.

\author{
Kozak K. \\ Ph.D., Associate Professor \\ Department of Management and Logistics \\ E-mail: kozakkate.coach@gmail.com \\ ORCID ID: 0000-0002-8099-6607 \\ Boychuk K. \\ The student of the fourth grade of Management, Marketing and Logistics Faculty \\ Odessa National Academy of Food Technologies \\ Kanatna str., 112 Odesa, Ukraine, 65039 \\ E-mail: likina.ua@gmail.com
}

\section{INNOVATIVE STAFF TRAINING TECHNOLOGIES}

The article discusses innovative technologies for staff training. These technologies are widely used in Europe, which contributes to effective economic growth of both the enterprise and the country as a whole. In the CIS countries and in Ukraine including, these technologies do not have a greater number of adherents. Domestic enterprises prefer the old proven technologies for years. Enterprises represented by man- 
agers do not always strive for innovations. For this there are a number of factors that hinder the company on the way to the introduction of innovations, the main thing is the impossibility of introducing innovations due to lack of funds or the company, which is committed to old technologies and does not strive for improvement.

The introduction of new technologies for staff training storytelling, shadowing, secondment, buddying will not entail high costs, will open up new opportunities for organizing work at the enterprise, which will entail a great potential for staff development. Innovative technologies consider the employee as an individual, take into account the individual needs for learning and obtaining new knowledge of each employee separately.

The article analyzes innovative methods of personnel training. The recommendations for the application of technology management and staff training in the enterprise has been given. The article describes the benefits that the company the manager and the employee, acquire the use of innovative technologies for personnel management. Examples are given of the consequences to be feared by the enterprise.

The examples of possible situations in which it is worth to use a particular training technology for the effective development of personnel have been considered. The methods to applying technologies that entail a steady growth of both the personal potential of each employee and the enterprise as a whole have been described. The principles on which innovative technologies are based are characterized. The recommendations for effective management and personnel training are offered, which enable the enterprise to get educated personnel. Using these technologies, the company educates the professional who will lead the company to a new economic level of development. buddying.

Key words: personnel management, staff training, employees, storytelling, shadowing, secondment,

\section{References}

1. AGROPROMGRUPA «PAN KURChAK». Retrieved February 01, 2019, from http://pankurchak.ua/

2. Novichkova, A. V., \& Vokresenskaya, Y. V. (2014). Storitelling kak sovremennyiy instrument upravleniya personalom. Internet-zhurnal «Naukovedenie», 6 (25)). Retrieved February 01, 2019, from https://naukovedenie.ru/PDF/39EVN614.pdf.

3. Kozak, K. B. (2012). Innovatsii v sferi upravlinnia personalom na pidpryiemstvi. Zernovi Produkty I Kombikormy, 1(4), 8-13.

4. Nastavnichestvo i storitelling kak sposobyi peredachi znaniy v rabochey srede. (2006). Retrieved February 01, 2019, from https://www.e-xecutive.ru/education/glavy-iz-knig/349726-nastavnichestvo-i-storitelling-kak-sposobyperedachi-znanii-v-rabochei-srede

5. Natsionalnyi bank Ukrainy. Retrieved February 01, 2019, from https://bank.gov.ua/control/uk/index

6. O metodah obucheniya i razvitiya personala. (2019). Retrieved February 01, 2019, from http://hrportal.ru/article/o-metodah-obucheniya-i-razvitiya-personala

7. Sovremennyie metodyi obucheniya personala. (2010). Retrieved February 01, 2019, from http://www.ngpc.ru/forum2010/Articles/Learnining methods.pdf

8. «Teni» $\mathrm{i}$ «druzya» - metodyi obucheniya personala, kotoryih u nas poka net. (2008). Retrieved February 01, 2019, from https://www.e-xecutive.ru/career/hr-management/344785-teni-i-druzya-metody-obucheniya-personalakotoryh-u-nas-poka-net?scrolltop=SCROLLTOP

9. Arranging a secondment: Practical and legal considerations. (2018). Retrieved February 01, 2019, from https://www.netlawman.co.uk/ia/secondment-agreements

10. Canwell, D., \& Sutherland, J. (2003). Student Resource Book for Edexcel. Cheltenham: Nelson Thornes.

11. Eight steps to a successful secondment. (2014). Retrieved February 01, 2019, from https://www.personneltoday.com/hr/eight-steps-to-a-successful-secondment/

12. How 2 Buddy. (2006). Retrieved February 01, 2019, from http://www.ayeconference.com/how-2-buddy/

13. Implementing a buddy system in the workplace. (2014). Retrieved February 01, 2019, from https://www.pmi.org/learning/library/implementing-buddy-system-workplace-9376

14. STORYTELLING: TRANSFERRING TACIT CORPORATE KNOWLEDGE IN DIFFERENT CULTURES A RESEARCH-IN-PROGRESS PAPER. Retrieved February 01, 2019, from http://ecsocman.hse.ru/data/918/655/1219/storytelling.pdf

Received 5 February 2019

Approved 19 February 2019 Available in Internet 19.03.2019

Цитування згідно ДСТУ 8302:2015

Козак К.Б., Бойчук К.Г. Інноваційні технології навчання персоналу // Економіка харчової промисловості. 2019. Т.11, вип. 1. C. 66-72; doi: 10.15673/fie.v11i1.1296

Cite as APA style citation

Kozak K., \& Boychuk K. (2019). Innovative staff training technologies. Food Industry Economics, 11(1), 66-72; doi: 10.15673/fie.v11i1.1296 